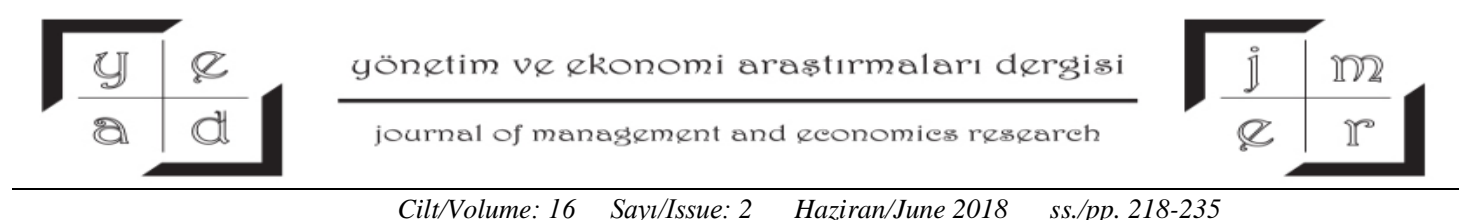

Cilt/Volume: $16 \quad$ Sayl/Issue: 2 Haziran/June 2018 ss./pp. 218-235

F. Pirinççi Doi: http://dx.doi.org/10.11611/yead.420421

\title{
SYRIAN CRISIS AND IRAQ: AN ANALYSIS ON THE EFFECTS ON MIGRATION AND RADICALIZATION
}

\section{Assoc. Prof. Ferhat PİRINÇÇi * iD}

\begin{abstract}
The popular uprising in Syria started in March 2011, and transformed a civil war that cannot be solved yet. Even the neighboring countries have been experiencing the outcomes of the crisis for more than seven years, it can be said that Iraq is one of the most influenced country from the Syrian crisis. Overall effects of the Syrian crisis on Iraq can be summarized in six different dimensions, such as migration, state structure, radicalization, economy, society and military capacity. The study aims to analyze the direct and indirect effects of Syrian crisis on Iraq by focusing on migration and radicalization dimensions. The study benefited from the literature review as well as the field research and interviews made in some Iraqi cities including Baghdad, Kirkuk, Najaf, Erbil, and Sulaymaniyah. In conclusion, given the problems it experienced after 2003, Iraq faced very negative externalities of the Syrian crisis.
\end{abstract}

Keywords: Syrian Crisis, Iraq, Internally Displaced Persons, Radicalization

JEL Codes: F50, F51, F52, F22

\section{SURIYYE KRİZI VE IRAK: GÖÇ VE RADİKALLEŞME ETKİSİ ÜZERİNE BİR ANALİZ}

ÖZ

Suriye'deki halk hareketi Mart 2011'de başlamış ve henüz çözülemeyen bir iç savaşa dönüşmüstür. Suriye'ye komşu ülkeler krizin sonuçlarını yedi yıldan fazla bir zamandır yaşasa da, Irak'ın krizden en fazla olumsuz etkilenen ülkelerden biri olduğu söylenebilir. Suriye krizinin Irak üzerindeki etkileri, göç, devlet yapısı, radikalleşme, ekonomi, toplum ve askeri alan olmak üzere altı farklı boyutta özetlenebilir. Bu çalışma Suriye krizinin Irak üzerindeki doğrudan ve dolaylı göç ve radikalleşme etkilerini analiz etmektedir. Çalışmada literatür taramasının yanı sıra Bağdat, Kerkük, Necef, Erbil ve Süleymaniye gibi kentlerde yapılan saha çalışmaları ve görüşmelerden yararlanilmıştır. Sonuç olarak Irak'ın 2003 yılından sonra yaşadı̆̆ sorunlar dikkate alındı̆̆ında, Irak’in Suriye krizinin oldukça negatif sonuçlarıyla karşılaştı̆̆ı görülmektedir.

Anahtar Kelimeler: Suriye Krizi, Irak, Yerinden Edilmiş Kişiler, Radikalleşme.

JEL Kodlart: F50, F51, F52, F22

\footnotetext{
* Uludağ Üniversitesi İ̈BF Uluslararası İlişkiler Bölümü, pirferhat@hotmail.com
} 


\section{INTRODUCTION}

The popular uprising in Syria was only a domestic problem in its initial phase. When it turned into a civil war, it started to affect the Middle East in different aspects. Lately, it has become a global concern, with the Syrian refugees and foreign terrorist fighters making the headlines. While no political solution is imminent in the near future, the Syrian crisis is one of the most complex problems in the political history with its cross border effects increasing day by day.

While the international community started to feel the direct consequences of the Syrian crisis and started to engage in a discussion about its resolution, the neighboring countries, namely, Turkey, Iraq, Jordan and Lebanon, were already dealing with the effects of the crisis since 2011. These four countries have been struggling to overcome the social, economic and political challenges caused by the Syrian crisis beyond, the scope of the refugees and security problems related to the ISIS. However, the effects of the Syrian crisis and the related developments on Iraq have been very different in comparison to the other neighboring countries.

As a neighboring country to Syria, Iraq has already been undergoing a major political crisis, before the onset of the Syrian crisis. The negative consequences of the policies pursued by the former Iraqi Prime Minister Nouri al-Maliki, especially during his second term after 2010, were intensified after the complete withdrawal of American troops by the end of 2011. Because of Maliki's sectarian and repressive policies, problems between Baghdad and Sunni-populated areas of the country, as well as between Baghdad and the Kurdistan Regional Government (KRG), were already there.

In this respect, taken together with Iraq's situation even before the Syrian crisis, it can be said that, Iraq is the most influenced regional country from the Syrian crisis in terms of security dimension. However, the effect of the Syrian crisis on Iraq has not been limited to the territorial security. Overall effects of the Syrian crisis on Iraq can be summarized in six different dimensions, such as migration, state structure, radicalization, economy, society and military capacity.

This study aims to analyze the direct and indirect effects of Syrian crisis on Iraq by focusing on migration and radicalization dimensions. The study benefited from the literature review as well as the field research and interviews made in some Iraqi cities including Baghdad, Kirkuk, Najaf, Erbil, and Sulaymaniyah. The study examines the migration effect of the Syrian crisis on Iraq in two aspects. One aspect is the refugee influx that affected all neighboring countries while Iraq has experienced another dimension as crisis' indirect repercussion, internally displaced persons (IDPs). Then the study focuses on the radicalization tendency and social effects of the crisis respectively.

\section{EFFECTS ON MIGRATION: LESS REFUGEE INFLUX, MORE IDPS}

In terms of migration, the effect of the Syrian crisis on Iraq must be evaluated in two different categories, namely, the people who fled from Syria to Iraq and those who voluntarily or forcefully 
became displaced within Iraq as IDP due to direct or indirect effects of the Syrian crisis. Nonetheless, it is also useful to mention that Iraq had already been subjected to the systematical internal displacement policies, even before the Syrian crisis. For instance, during the Saddam period, forcing the people to live in some parts of the country or leave their homes was a political tool used to change the demographics of the country. Similar policies were still being used in the post-Saddam Iraq. Moreover, political tensions and instability in Iraq, which emerged after the overthrow of the Saddam regime and increased incrementally together with the repressive policies of the Maliki government, had already deepened the problems related with Iraqi refugees and displaced persons in Iraq, long before the Syrian crisis. In this sense, according to the United Nations High Commissioner for Refugees' (UNHCR) 2007 estimates, while 2,256,000 Iraqis were forcefully displaced within the country, those between 2 million and 2.5 million had to immigrate to other countries because of security-related reasons.

Table 1. Internally Displaced Persons in Iraq according to the Region (2007)

\begin{tabular}{|l|l|}
\hline Iraq & $2,256.000$ \\
\hline Syria & $1.2-1.4$ million \\
\hline Jordan & $500,000-750,000$ \\
\hline Egypt & 70,000 \\
\hline Iran & 57,000 \\
\hline Lebanon & $20,000-40,000$ \\
\hline Turkey & 10,000 \\
\hline Other Gulf countries & 200,000 \\
\hline Total (minimum estimate) & $4,313,000$ \\
\hline Total (maximum estimate) & $\mathbf{4 , 7 8 3 , 0 0 0}$ \\
\hline
\end{tabular}

Source: UNHCR, Statistics on Displaced Iraqis around the World, September 2007, http://www.unhcr.org/470387fc2.html

Problems pertaining to migration and internal displacement in Iraq, which occurred after the American invasion in 2003 and incrementally increased by the post-2006 developments, had actually were being reversed during the earlier stages of the Syrian crisis. According to the UNHCR (2013) estimates, while more than 600,000 emigrated Iraqi people returned to their country, 1.2 million internally displaced Iraqis also returned their homes between the years of 2003 and 2012. However, despite these figures, 1.1 million Iraqis were still internally displaced within the country at that time. Accordingly, Iraq had already been a country known for internal and external population movements before the Syrian crisis. However, the Syrian crisis undoubtedly contributed to this situation negatively. As a result of either refugee influx from Syria or the expansion of ISIS in Iraq, the numbers of both refugees and internally displaced Iraqis showed a considerable increase in Iraq.

\subsection{Refugees from Syria}

The refugee movements toward Iraq due to the Syrian crisis differ from those toward other regional countries in some particular aspects. In this sense, it is important to note that Iraq received the 
least number of the Syrian refugees, in comparison to the other neighbors of Syria. According to the UNHCR data (2018a), as the graph 1 illustrates below, Turkey hosts 3,578,246 Syrians from Syria, while Lebanon follows it with almost 1 million Syrians, and Jordan with 661,859. The number of Syrian refugees in Iraq has only been around 248,382, which constitutes about $4.4 \%$ of the total refugee burden handled by the other neighboring countries.

\section{Graph 1. Syrian Refugee Distribution in the Region}

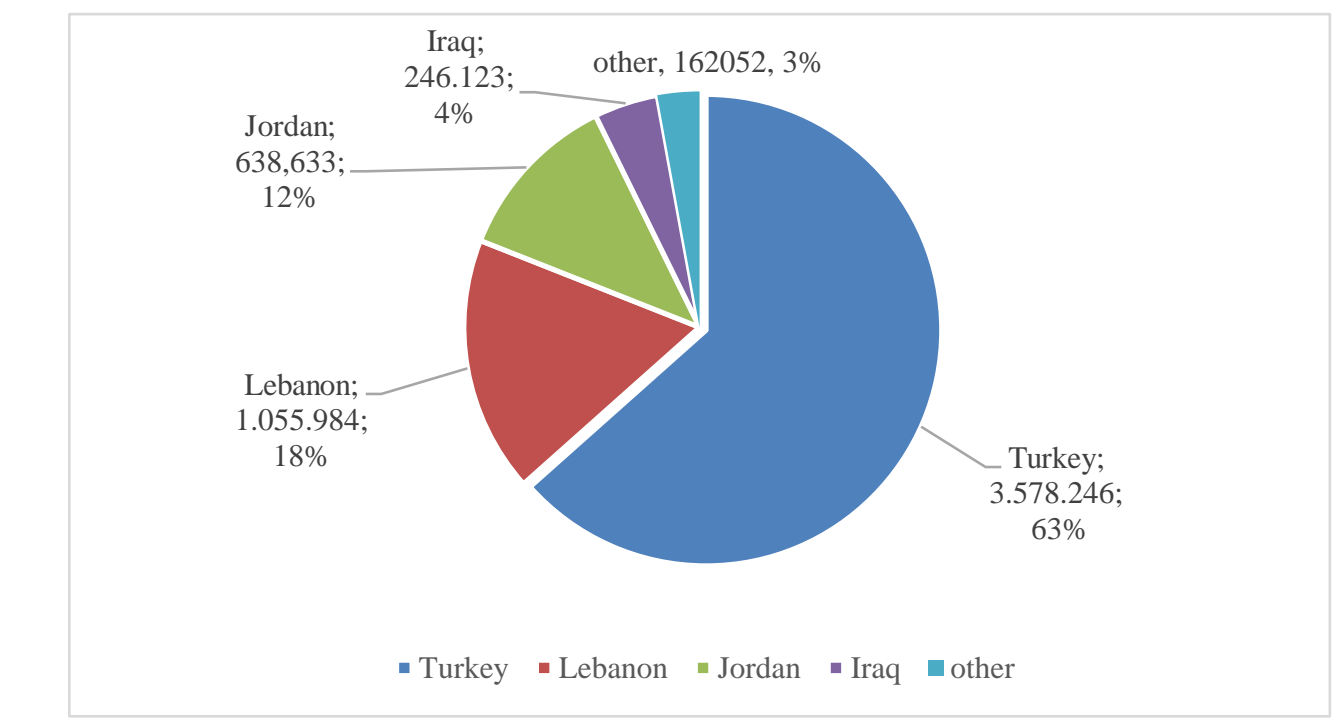

Source: UNHCR, Syria Regional Refugee Response, http://data.unhcr.org/syrianrefugees/regional.php

Secondly, in comparison with the other countries in the region, refugee movements toward Iraq began relatively later, about a year after the eruption of the crisis in Syria. As the Syrian crisis started in March 2011, according to UNHCR (2018a) the total number of Syrian refugees in Iraq was only 180 by the beginning of March 2012, while during the same period there were 10,658 refugees in Turkey, 7,058 in Lebanon, and more than 3.000 in Jordan.

Thirdly, unlike Turkey, Lebanon and Jordan, Iraqi government did not follow an open door policy for the Syrian refugees, due to its existing internal instability. In this sense, it is important to note that the Iraqi central government and the KRG pursued different policies towards the Syrian refugees. Even though Baghdad decided to open Rabia and al-Qaim border gates for the entrance of the Syrian refugees, whose amounts were ever-increasing, and started to place them in refugee camps in July 2012, this policy did not last much longer. It decided to close the border-crossing in a month for the Syrian refugees, except in only some particular cases. Moreover, the refugees who were settled in areas outside of the KRG's control were not given the right to work and mobility outside the camps. They were only allowed to receive basic services. The KRG, in comparison with the Baghdad government, pursued more flexible policies by avoiding from forcing the Syrian refugees to live only 
in designated areas, which was the practice of the central government. In addition to allowing Syrian refugees to receive basic services, the KRG has also pursued open door policy with few exceptions.

Fourthly, given this flexible policy of the KRG, Syrian migration towards Iraq has largely oriented toward the KRG area. In addition to the geographical proximity, commonalities between the Syrian refugees and Iraqi Kurds in ethnic, social, and cultural terms also played an important role in the refugees' decision to move to the KRG territories. In this sense, even though the UNHCR (2015) does not categorize Syrian refugees in Iraq ethnically, it is estimated that Syrian migration toward Iraq has mostly hailed from the Kurdish populated regions in Syria. It is reported that more than $57 \%$ of the Syrian refugees in Iraq came from Hasakah, about 25\% from Aleppo, and about $9.36 \%$ from Damascus, while only $7.86 \%$ from the rest of the country.

\section{Graph 2. The Places Syrian Refugees Settled in Iraq}

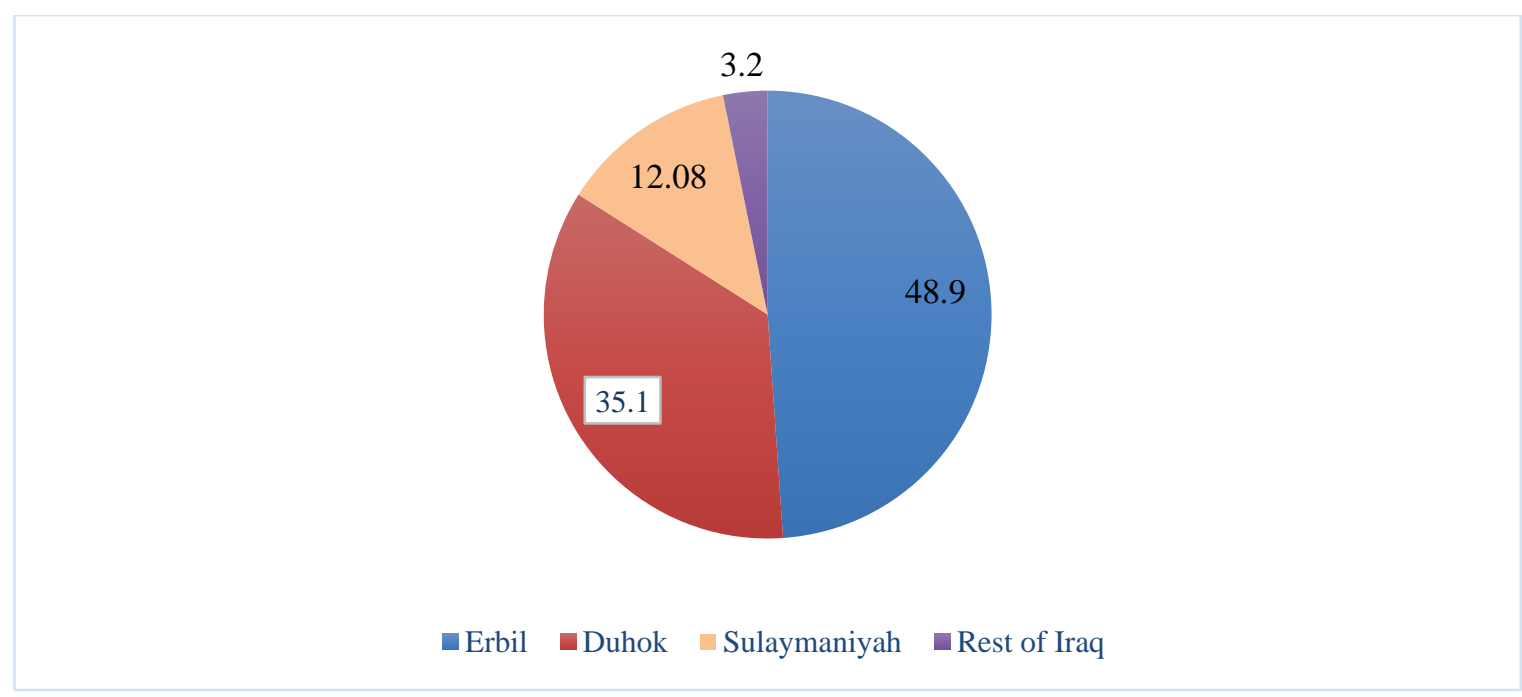

Source: UNHCR, Registration Trends for Syrian Persons of Concern https://data2.unhcr.org/en/situations/syria/location/5

According to the UNHCR (2018b) data, 248,382 Syrians fled to Iraq. As Graph 2 shows, of those Syrians, $48.9 \%$ settled in and around the Erbil area, 35.1\% in Dohuk and its rural areas, while about $12.08 \%$ chose Sulaymaniyah and its environs. In other words, $96.8 \%$ of those people who fled from Syria to Iraq settled in territories under the control of the KRG. About $37 \%$ of these Syrians live in the refugee camps and temporary settlement areas, while about $63 \%$ live in the cities.

Moreover, after the crisis in Syria erupted, increasing pressure of the Assad regime on the Sunni Arabs led them to flee toward Iraq as well. Considering common tribal and kinship ties shared between the Iraqis and Syrian Sunnis, the latter preferred Iraq as well. Thus, movement through Mosul and Anbar provinces of Iraq, which formed the largest part of the Syrian-Iraqi border, gained momentum especially after 2012. This even led the Syrian regime to demand Iraq to more strictly control the border in order to prevent border crossings toward Syria. However, considering various factors such as the length of the border, the geographical conditions and the existence of different groups controlling the border areas, the crossings between the two countries could not be prevented. 
To sum up, even though Iraq's role in accepting Syrian refugees is highly limited in comparison with the other neighboring countries of Syria, the settlement of a large part of the Syrian refugees in the areas under the KRG control has increased the burden of the KRG. Although the total number of Syrian refugees in Iraq was less than other neighbors, this problem was aggravated as it overlapped with other issues, such as the disagreements between Baghdad and Erbil on the distribution of oil revenues as well as the issue of disputed territories. This became particularly visible especially after the summer of 2014, when ISIS entered the picture in Iraq as well.

\subsection{ISIS-Related IDPs}

IDP issue has been a reality for Iraq for decades, long before the outbreak of the Syrian crisis. During the Saddam era, Arab Shiites, Kurds and the Turkmen people were forced out of their homes as a state policy in an attempt to re-design the demographical structure of the country in favor of the regime. Even though there is no reliable information on this issue, it is estimated that nearly 1 million people were forcefully displaced during the Saddam era. (Fawcet-Cohen, 2002) As seen in today's discussions about the status of Kirkuk and other disputed territories, Iraq still could not solve the negative consequences stemming from the demographical practices of the Saddam era. Taken together with the new IDPs in the post-Saddam era, it is legitimate to predict that the problem of the IDPs will potentially affect the political and social integrity of Iraq in the future.

Following the US invasion of Iraq in 2003, it was estimated that more than 150,000 Iraqis had been displaced between the years of 2003 and 2004, some of which was due to the sectarian-motivated revanchist attitudes by the Arab Shiites towards especially Sunni people. Considering other developments, especially the insurgency against the United States, the issue of displacement continued afterwards. The UNHCR estimated the number of displaced Iraqi people at around 1.6 million by the end of 2006. Although the number Iraqi IDPs decreased to 1.1 million in 2014, growing societal discontent stemming from the sectarian-based policies of exclusion pursued by the Maliki government especially toward Sunni-populated parts of the country, as well as intensified conflicts between Sunni groups and the Iraqi army, resulted in a considerable rebounding in the number of Iraqi IDPs. This rebounding came before the rise of the ISIS in Iraq, which was a spillover of the Syrian crisis. For instance, even before the ISIS invasion of Mosul in June 2014, 480,000 Iraqis were also forced to leave their homes by the end of 2013, due to the conflicts erupting between the Sunni groups and the Iraqi Army.

Until 2014, the problem of IDPs had largely been an internal issue for Iraq, which had also partially affected other countries in the region. Parallel to the growing influence of the Syrian crisis on other regional countries, the effect of external factors on Iraq's IDPs problem has increased. In the aftermath of the Mosul invasion by the ISIS, nearly 1.2 million Iraqis became IDPs, as a result of the ISIS attacks between June and August 2014. According to Internal Displacement Monitoring Centre 
(2017), as a result of both the ISIS attacks and the campaign initiated by the US-led international coalition ISIS, 1,378,000 additional Iraqis were forced to leave their homes and turned into IDPs, during the term between September 2014 and June 2015.

ISIS expansion in Iraq, which is an indirect effect of the Syrian crisis, and the operations against ISIS created a new wave of IDPs, which has triggered a number of problems such as expansion of societal radicalization, the disruption of economic activities, the breakdown of the state structure and the extinction of multi-culturalism. According to the International Organization for Migration's Displacement Tracking Matrix (2018), displacements in Iraq intensified especially in the middle and northern parts of the country. Displacements in Iraq are largely originated from Anbar, Nineveh (Mosul), and Saladin (Tikrit) provinces, which account for 87\%. Among these provinces, Anbar is the most affected one from the IDP problem in Iraq, with $42 \%$.

Moreover, the new problems caused by the ISIS threat affected predominantly Sunni Arabs in Anbar, while in the other two cities, other groups including the Turkmen, Yezidis, Christians and Shebeks were also affected, who were forced to move other areas in Iraq or abroad. The conditions of especially the Turkmen population in Mosul and Saladin are important. For instance, it is reported that nearly 450,000 Turkmen people living in Tel Afar, which is a town of Mosul, were forced to leave their homes. Likewise, Turkmen-populated villages, districts and small towns which are administratively parts of Mosul were subjected to displacements toward other areas. Similarly, Turkmen people who live in and around Tuzkhurmatu, which is a Turkmen-populated town of Saladin, were forced to leave their homes.

It is also important to note that the data regarding the Iraqi IDPs provided by different sources may show some serious differences, due to the impossibility of an extensive field-research in conflict zones. Hence, the Internal Displacement Monitoring Centre has reported the number of Iraqi IDPs as over 4 million by 2015, while this number was about 3 million according to the Office for the Coordination of Humanitarian Affairs (OCHA) at that time. The UNHCR (2015) data, on the other hand, estimated the number of Iraqi IDPs -as well as other persons within the country close to the IDP status- as over 3.5 million, as of 2014. At the time of writing this article according to International Organization for Migration (2018) there were still nearly 2,5 million IDPs present in Iraq while more than 3,6 million former IDPs returned their homes.

Despite the incoherence between the estimates developed by different agencies, their common point is the growing trend in the problem of IDPs in Iraq, which started to escalate after the ISIS attacks in December 2013 and reached incomparably higher levels than the previous waves of IDPs. Moreover, these displacement strategies are strategically used to change demography and the political geography in the country, sometimes under the pretext of fighting ISIS threat. 


\section{EFFECTS ON RADICALIZATION}

Another effect of the Syrian crisis on Iraq has been growing polarization and radicalization among different groups in the country. This growing tendency of radicalism has not only included certain parts of the Iraqi society, but it has affected almost all groups in Iraq by reinforcing itself mutually among the opposite groups in the society. In this context, it is possible to claim that the Sunni Arabs, Shia Arabs as well as partially the Kurdish groups in Iraq have developed new radical tendencies, as a result of the effect of the Syrian crisis on the country.

Nevertheless, radicalization tendencies in Iraq cannot be attributed to the Syrian crisis alone. There had already been a Sunni Arab insurgence in Iraq since the American invasion in 2003. Immediately after the invasion, "de-Baathification" strategy of the Coalition Provisional Authority led to the deposal of all Sunni political and military elites from their positions, together with the dismissal of all security agencies and the army of the old regime. However, the exclusion of Sunni Arabs from the newly formed system in Iraq led to their radicalization. Overall, the main components of the Sunni insurgence in Iraq include the people who were pro-Saddam or the Ba'athists, the people who were Sunni Arab nationalists, the people who were Sunni Islamists, the radical groups who had voluntarily came to Iraq, and the paid guerillas.

Number of the Sunni insurgents who organized attacks on the Iraqi security forces and the US forces in Iraq was estimated about 5,000 by the end of 2003, then it was reported that the number reached about the level of 20,000-30,000 as of July 2004. (Hoffman, 2004: 12) However, Iraqi insurgents insisted that they were about 100,000 together with the militia forces as of January 2014. (Iraq News Net, 2014) Regardless of the numbers, Sunni insurgents had considerable influence on the re-construction of Iraq in the post-2003 process. Consequently, the U.S. also took note of this situation and then tried to re-integrate the Sunni tribes as well as some of the ex-Ba'ath members and the former military leaders in the state structure. Furthermore, as part of the drive for reconciliation with some influential Sunni tribes in Iraq, the U.S. supported the formation of the Sahwa Councils ( "Awakening" Forces, also known as "the Sons of Iraq") which was established by the Sunni tribes in order to drive the radical groups out of the country. Eventually, the room of maneuver for the foreign radical groups was seriously narrowed in Iraq between the years of 2007 and 2008.

Even though there was no certain data for the number of foreign fighters who participated into the Sunni insurgent groups that fought against the Iraqi security forces and the American troops in Iraq, it was acknowledged that those foreign fighters were highly experienced in fighting tactics, but were considerably lower than the other Sunni Iraqi insurgents. For instance, according to the report published by the Bureau of Counterterrorism of the U.S. Department of State in April 2006, only about $4-10 \%$ of the Sunni insurgents in Iraq were foreign fighters who were non-Iraqis and came from outside the country. Moreover, a great majority of these foreign fighters were fighting under the Al- 
Qaeda. However, despite considerable military advances of the US-supported Sahwa Forces formed by the Sunni tribes against the foreign radical groups, in the process of re-integration of Sunni Arabs into the newly formed political and military system of Iraq experienced failures. Such failures have fueled the resurgence of these foreign radicals, and their ability to attract local participation. In other words, the policies pursued by the government of Baghdad, which were seen as sectarian by Iraqi Sunnis, have played an important role during the transformation of Al-Qaeda in Iraq into the ISIS. The ISIS later found fertile ground in Syria to expand its initial military capacity and then penetrate back into Iraq as more powerful actor than in the past.

\subsection{Radicalization among Sunni Arabs}

Regarding the radicalization tendencies among Sunni Arab, the case of invasion of Mosul by ISIS can be taken as an important indicator. It should be kept in mind that, ISIS has not encountered any local resistance during its Mosul invasion in June 2014 and then it has easily established control over other Sunni Arab populated areas in the country. On this issue, the previous social discontent among the Iraqi Sunnis played a major role here. In other words, Sunni local support gained by ISIS in Iraq was not built by the Mosul invasion, but it was a result of the accumulated societal tensions since the American invasion in 2003.

Although the reaction among Sunni Arabs started to decline together with the US-supported attempts to re-integrate Iraqi Sunnis into the new system between 2005 and 2008, the policies pursued by Maliki afterwards, especially during his second political term, increased radical tendencies among most parts of the Iraqi Sunni Arabs. In this sense, the conflicts intensified in December 2013, which led to the displacement of almost 500,000 Iraqi people. Such dynamics also played an important role in raising radical tendencies among the Sunni Arabs in the country. Consequently, when ISIS turned back to Iraq after its Syrian experience, in which the group built its initial military capacity, a considerable amount of Iraqi Sunnis had already been radicalized, or at least, they were inclined for radicalization.

The ISIS was not received as an occupation force by all parts of the local people in the regions under its control. On the contrary, some of the Iraqi Sunnis considered ISIS as an alternative which would save them from the Shia pressure by helping re-establish the Sunni Arab political power in the country. Some others considered it as an authority that would be able to implement the Islamic rules effectively in the country. Consequently, when the ISIS invaded Mosul, it was welcomed by the local supporters, instead of facing major resistance, largely because of such factors.(Lefler, 2014) In the process, ISIS has increased immigration and internal displacements of a number of minority groups as well as the Shiites. A considerable number of the local Sunni population were living in the regions that later fell under ISIS control. Although the exact number of people who live in the areas under ISIScontrol remained vague, the estimates were around 8 and 10 million.(Collard, 2014) Meanwhile, many 
Sunni Arabs were displaced as well. In most cases, they experienced very difficult times as IDPs in different parts of Iraq.

During the interviews, some Iraqi Sunnis, who were forced to flee their homes due to ISIS attacks, told that they prefer immigration to the ISIS-controlled areas because there is public order and they have better alternatives in comparison to difficult living conditions existing in the regions where they seek shelter. Also during the interviews, it was observed that some Iraqi people, who had been forced to move to Kirkuk by fleeing their homes in Tel Afar and other regions, were trying to return liberated areas but they had major problems.

To sum up, the radicalization tendencies among the Sunni Arabs already existed before the Syrian crisis. The crisis erupting in Syria has given a new momentum to these radicalization tendencies. The ISIS has been seen as the first serious alternative to the Shia-dominated Baghdad government in post-2003 Iraq by the Sunni Arabs. Moreover, as it will be discussed below, during the campaign against the ISIS which began in the aftermath of Mosul invasion, a great number of revanchist behaviors towards the Sunni population who live in the regions retaken from the ISIS control were reported. These revanchist behaviors or speculations of particularly certain Shiite militia served to escalate radicalization tendencies among the Sunni Arabs. Accordingly, it is important to highlight that the radicalization problem among the Sunni Arabs is likely to transform into a vicious cycle. Consequently, this radicalization problem presents a quite serious threat before the stability in Iraq.

\subsection{Radicalization among Shiites}

Sunni Arabs are not the only radicalizing group in Iraq; some other serious radical tendencies have also emerged. There has been escalation of the Shia radicalization in Iraq as well. Shia groups were already engaging in paramilitary activities before the crisis. There were especially two groups among the Shia militias that were mostly known: the Badr Brigades, which was established as the military wing of the Supreme Council for the Islamic Revolution of Iraq during the Iran-Iraq War, and the Mehdi Army of Muqtada al-Sadr, which became prominent after the American invasion of Iraq in 2003. These groups were filling a considerable security gap for the Shia society in the post-2003 Iraq, where the army and security units were dismissed after the overthrow of the Saddam regime. They have also paid a particular attention to avoid practices which would put the Baghdad government in a difficult position. During the reconstruction process of the Iraqi army, filling of the most important military positions, notably command echelon, with the Shiites incentivized other Shiite groups to be militarized in terms of military training and armament.

After 2003 the overall security situation in Iraq was deteriorating. Even though the bomb attacks against the civilians as well as the security forces of Iraq went into a decline in 2008, they started to rise again after 2011. A great majority of those attacks were said to be carried out by the Sunni radical 
groups which were dealt above. Thus, Iraqi security forces and the Shiites usually became the main targets of those attacks. While the Iraqi Army used conventional ways to struggle with those attacks, the Shiite militias fueled the continuation of this process, through their attacks against the Sunnis. For instance, the Shiite paramilitary groups conducted a number of revanchist attacks and bombings in Sunni-populated regions, while the Iraqi central government was continuing its struggle with the Sunni groups. Accordingly, it is possible to assert that radical tendencies already existed among the Iraqi Shiites long before the Syrian crisis. However, the Syrian crisis and its resulting effects after the rise of ISIS have added a new dimension onto the existing radicalization tendency among the Iraqi Shiites.

ISIS's invasion of Mosul shook the political system in Iraq, which had been dominated by the Shiites since 2003, though it was vulnerable. After the Mosul invasion in June 2014, ISIS invaded also Anbar, Tikrit, Diyala and the southern parts of Kirkuk. These advances brought the ISIS close to Baghdad and Samarra, where some important sacred places for the Shia exist. Thus, the Iraqi Shiites started to regard the ISIS expansion as an existential threat for their sectarian identity. The escalating tensions and increased apprehensions in sectarian terms led al-Sistani to call for jihad against ISIS on 12 June 2014. Immediately after al-Sistani's fatwa for jihad, tens of thousands Iraqi Shiites appealed to fight for al-Hashd al-Shaabi militias. Even though al-Hashd al-Shaabi was initially established with the aim of supporting the Iraqi Army and other security forces against the ISIS, over time, it has become a prominent actor, largely independent of the Iraqi Army.

In addition to the risks that may stem from uncontrolled violent actions of the Iraqi security forces in Sunni-populated regions of Iraq, al-Hashd al-Shaabi, whose size is estimated to be between 50,000 and 90,000 paramilitary fighters, has the potential to become a serious threat for the future of the country, unless necessary measures to control it are taken timely. Undoubtedly, there are some groups and people who joined the militias of al-Hasd al-Shaabi with the aim of preserving or retaking their regions from ISIS. However, some factors such as the establishment of this umbrella organization together with al-Sistani's fatwa for jihad, the formation of its forces predominantly by the Shiites, and the obvious Iranian support behind it in terms of organization, training and operations, led non-Shiite parts of the Iraqi people to become suspicious towards that militia organization. (Duman, 2015a: 1114) Furthermore, in addition to the casualties suffered by al-Hashd al-Shaabi in its fight against ISIS, violent attitudes of its militias towards the local people in the areas retaken from the ISIS pave the way for the escalation of radicalism as a problem which re-produces itself continuously between the Shiites and the Sunnis.

\subsection{Radicalization among Kurdish Groups}

The Syrian crisis and its repercussions have also affected the Kurdish people in Iraq, despite its relatively lesser extent in comparison to its effects on the Shiites and the Sunnis in Iraq. Kurdish groups had problematic relations with the central government in Iraq until the overthrow of the 
Saddam regime. However, the situation started to change during the post-Saddam era. Together with the new constitution in 2005, Erbil, Dohuk, and Sulaymaniyah, provinces with Kurdish majority population, have gained an official status as the Kurdistan Regional Government of Iraq. Kurdish groups who had already been motivated by nationalist and geographical references became part of the political processes in Baghdad, under the newly formed system of Iraq. Moreover, the presidency of the Iraqi state was allocated to the Kurds as part of the power sharing arrangements. Nevertheless, the symbolic authority of the Iraqi president in contrast to the complete executive authority of the Iraqi Prime Minister, who was elected among the Shiites, could not help reduce the growing tensions between Baghdad and Erbil. During this process, the Peshmerga, Kurdish armed group, grew as a militarily well-skilled force, and was recognized by the Iraqi legal system.

In the post-Saddam Era, it was generally assumed that the Peshmerga lost its strong military capacity as a result of both its transformation to the regular military units and, most importantly, the improvement of the KRG's stability in both security and economic terms in comparison to the other regions of the country. Nonetheless, during Maliki's term, the tense relations between Baghdad and Erbil due to the disagreements over the distribution of oil revenues and the problem of disputed territories, particularly Kirkuk's status, the need for Peshmerga increased, as the threat perceptions of the Kurds rose. Moreover, some structural problems that emerged during the reconstruction process of the Iraqi Army after 2003 resulted in the Iraqi Army's failure to consolidate full security in the areas other than the southern part of the country. Consequently, structural problems of the Iraqi Army in its reconstruction process prevented its military units from exercising control over the Peshmerga, which allowed the latter greater latitude.

The Syrian crisis and the rise of ISIS increased threat perceptions of the Iraqi Kurds further. However, the tensions between Baghdad and Erbil were postponed as a rather positive reflection of the Syrian crisis. In this context, when ISIS invaded Mosul and moved towards Kirkuk, the Peshmerga immediately reacted and brought Kirkuk under its control. After ISIS invaded Sinjar, which is a Kurdish-populated town, it advanced towards Erbil, approaching 40-50 kilometers to the city. This development became a turning point for the Kurdish people in Iraq. (Duman, 2015b: 58-59) While this situation led the Iraqi Kurds to feel an existential threat, increasing number of Syrian refugees as well as IDPs raised the challenges before the Kurdish aspirations. The growing security considerations among the Iraqi Kurds contributed to the suspension of both the tensions between Baghdad and Erbil and also the intra-Kurdish tensions, at least in the short-term. However, due to this heightened threat perception among the Iraqi Kurds as they were concerned about the existence of their national identity and the KRG, some Kurdish actors also developed a further radicalized attitude towards both the Sunni Arabs and the Shiites.

To sum up, it is possible to claim that the Syrian crisis and its repercussions have contributed to the increase in radicalization in Iraq. The rising trend of radicalization in Iraq affect all Iraqis who are 
either perpetrators or victims of this process. However, the radical tendencies are especially intensified among the Sunni Arabs and the Shiites in Iraq. As it will be mentioned below, although a number of ethnic and religious minorities are affected by this new wave of radicalization, the group that suffered the most in this process has become the Turkmens. At any rate, fighting the effects of radicalization will take quite a long time due to its self-perpetuating characteristics, even if the ISIS is eradicated and Syrian crisis is ended. Therefore, radicalization will be a major problem in the future of Iraqi politics and society.

\section{REPERCUSSIONS ON IRAQI SOCIETY}

The Syrian crisis has inevitably created some societal effects on Iraq. These societal effects which are related to the other ones resulted in the emergence of humanitarian problems which are hard to recover in the short-term. Most of humanitarian problems are man-made and products of the conflict. All the groups in Iraq which have armed forces invariably use their military capacity as an element of oppression and gains against the civilians, or at least the people who have relatively weak military power. The crisis in Syria and the expansion of ISIS through its drastic attacks and gains in Iraq have added a new dimension to the humanitarian emergencies. As noted above, the displacement of Iraqis on the basis of ethnic, sectarian, or political identities was already a problem for the Iraqis, even before the Syrian crisis. After the Syrian crisis, the displacements in Iraq started to be encountered more frequently at various degrees. Consequently, it can be noted that the Syrian crisis turned the IDP problem in Iraq into a more dangerous threat for the country's societal integrity, than was the case before.

As a result of these deliberately implemented policies of displacement in Iraq, in addition to the emergence of humanitarian tragedy, the demographical borders started to be redrawn, multiculturalism started to be undone, while certain ethnic/sectarian concentrations emerged in particular regions of the country. This situation undoubtedly threatens the social integrity and the future of Iraq, while it also poses a serious risk to increase radicalization in the country.

In the modern history of Iraq, displacements were used politically. This policy firstly emerged in the 1970s, then passed two turning points during the Saddam period: the Iran-Iraq War in the 1980s and the Gulf War in 1990-91. During this period, the displacements were state-led activities which were carried out by using security forces, mainly against the Kurdish people, and also the Arab Shiites partially. By the year of 2003, it was reported that about 1 million Iraqi people had been internally displaced in the country. (Lischer, 2008: 102-103) However, after 2003, while the main actor of displacements became militias and other paramilitary groups rather than the state, the Sunnis and Turkmen were targeted. As a result of the policies implemented during the post-2003 era, and especially after 2006, the UNHCR reported that the number of internally displaced Iraqis rose from 1 million to 2 million by 2007. The number of IDPs reported by various sources differs from each other 
due to the different measures, and/or problems in recording. For instance, even though the Iraqi government announced the number of internally displaced Iraqis as 759,000 at the end of 2013, the exact number was believed to be much higher. (International Organization for Migration, 2013) If the map of Iraqi displacements which was prepared by using the statistics of the government from November 2013 is considered, it is possible to see that the displacements happened mostly in Baghdad and Nineveh, as well as Kirkuk and Anbar. A great majority of displaced groups in these regions were the Sunni Arabs. Before the ISIS invasion of Mosul, during the first five months of 2014, 480,000 Iraqis were displaced only in Anbar due to intensified conflicts between the security forces and the radical groups in the city. (Internal Displacement Monitoring Centre , 2017)

With the rise of the ISIS which was triggered by the Syrian crisis, and its invasion of Mosul, forceful displacement policies of Iraqis took a different shape. Displacements and forcible migrations have started to be carried out by four different actors with their different goals. These actors include the ISIS, the Iraqi Army, the predominantly Shiite militias, and the Peshmerga. In this context, according to UNHCR (2014) after the invasion of Mosul, it was reported that about 300,000 people had to leave their homes in less than a week. Following the ISIS invasion of Sinjar on 2 August 2014, about 200,000 more people had to leave the region. The most suffered communities from the ISIS attacks were the Shiites, the Turkmens, the Yezidis, and the Kurds in this context. Furthermore, even some of the Sunnis who did not support the ISIS operations left their homes because of security reasons. Consequently, according to (Internal Displacement Monitoring Centre (2017) after the intensified attacks of the ISIS especially in Mosul and its surrounding area from June to August 2014, about 1.2 million Iraqis reported to become internally displaced.

Despite the failure of the Iraqi Army in offering an effective defense against the ISIS advance, its military operations against the ISIS contributed to the continuation of displacements of the Iraqi people. Moreover, in addition to its non-institutional structure, the operations of the al-Hashd alShaabi led to some new displacements in the areas it controlled. According to some observers, similar to the ISIS's violent methods, the revanchist attacks carried out by the al-Hashd al-Shaabi and the Iraqi Army were documented on the social media, during especially the earlier period of the anti-ISIS fighting. Some of the NGOs attempted to warn against a possible repetition of such revanchist attacks in Iraq. For instance, the Human Rights Watch (HRW) (2015a) published a report in March 2015, which was titled "Came Destruction: Iraqi Militias and the Aftermath of Amirli," in which it investigated the post-ISIS conditions of the areas in and around Amirli. The report especially shows the plundering and arson crimes committed by the Shiite militias as well as the Iraqi security forces in the areas left by the displaced people. In addition, the report prepared by using eyewitness' testimonies, fieldwork and the satellite images concluded that some villages were totally destroyed due to these operations conducted by the Shiite militias and the Iraqi security forces. For instance, as a 
result of the fieldwork research in an area about $500 \mathrm{~km}^{2}$ in size near Amirli, the report confirmed that 30 of the total 35 buildings were destroyed after the end of the ISIS control.

During the anti-ISIS campaigns, operations conducted by the Peshmerga pose some serious risks for the security of the Iraqi people in the long term. For instance, some available data suggest that the Peshmerga prevented the return of inhabitants - especially the Arabs- to their homes in some areas, even after the end of ISIS control. In this context, the report published by the HRW (2015b) in February 2015, titled "Iraqi Kurdistan: Arabs Displaced, Cordoned Off, Detained" shows that the Peshmerga imprisoned Arabs in "the security zones" which had already been retaken from the ISIS control. According to the report, the Peshmerga and the local security forces prevented the displaced Arabs from returning to their homes in Erbil and Ninawa because of the security reasons. Such restrictions, however, did not apply to the Kurdish people who had previously been living in these provinces together with the Arabs. The report also indicates numerous arbitrary detentions and plundering crimes perpetrated by the KRG forces towards the Arabs and their homes in the regions, which were retaken from the ISIS. Similarly, the report also reveals some serious plundering crimes acted by the Peshmerga in Tel Uskuf, a predominantly Christian-populated area, even after the end of ISIS control. Another problematic part of this development is that these plundered areas by the Peshmerga were previously under the control of the central government, not the KRG, as noted in the report.

The prevalent insecurity together with the ISIS threat led to the intensification of security measures all across the country. However, during our fieldwork in Iraq, we observed that non-Kurdish -but especially Arab- people who were travelling from Kirkuk to Erbil were subjected to more strict security controls and the police inquiry than those of Kurdish origin at the entrance of Erbil on the Kirkuk-Erbil highway. Such measures are potentially feeding intra-communal tensions across the country.

Kirkuk has become one of the most affected areas from the crisis. Namely, while Kirkuk was being threatened by the ISIS on the one hand, it also witnessed an implicit power struggle between different anti-ISIS armed groups, on the other. This chaotic atmosphere inevitably threatens the security of the people, either the inhabitants who had already been living in Kirkuk before the crisis, or newcomers who had fled from the ISIS attacks. Especially the Turkmens have been affected from this development disproportionately. Thus, geography of Turkmen population in Iraq has considerably been changed as a result of either the invasion of some Turkmen regions by the ISIS, or other areas turning into the battlefronts against the ISIS. For instance, about $95-97 \%$ of the people who lived in Tal Afar district of Mosul, where the population was about 520,000 and the majority was made of the Turkmens, had been displaced, while many other Turkmen villages of Mosul had also been evacuated. Some of the Turkmens who immigrated from Tal Afar had taken refuge in Najaf, Karbala, and Babel, while some others had immigrated to the other Iraqi cities such as Dohuk, Erbil and Kirkuk. Besides 
these internal displacements, some Turkmens had emigrated from Tal Afar and other places to Turkey as well. In addition to Tal Afar, Tuz Khurmatu district of Saladin province where the population was formed by Turkmen majority also witnessed refugee movements.

To sum up, the forced migration or internal displacements of the Iraqi people due to security reasons have negative societal effects on Iraq in the long-term, regardless of the perpetrator, which, depending on the context, may be one of those: the ISIS, the Iraqi Army, the Shiite militias, the Peshmerga, or any other armed groups. The motivations behind these displacements, the authorities' willingness to prevent them or allow returns to the areas liberated from the ISIS are political. The policy responses to displacement are not triggered by actual security conditions, as much as they are by specific political agendas. The political motivations of different actors mainly seek to achieve ethnic and, or sectarian concentration in the regions under their control.

\section{CONCLUSION}

The effects of the Syrian crisis and the related developments on Iraq have been very different in comparison to the other neighboring countries. The most remarkable difference has been the weakening of the national integrity of Iraq, while in terms of territorial integrity, it came to the verge of disintegration. The crisis inevitably had an effect in terms of immigration and population movements. Although there was a lower rate of immigration from Syria to Iraq in comparison to the other regional countries, the problems posed by the IDPs were much deeper for Iraq than the others. This situation is closely related to the evolution of and rise in radicalization in Iraq. Hence, the incremental trend of radicalization affects all parts of the Iraqi society, who are either perpetrators or victims in this process. In this sense, it is possible to note that radical tendencies in Iraq have been intensified, especially among the Sunni Arabs and the Shiites. While a large number of ethnic and religious minorities have been affected by the growing radicalization in Iraq, the Turkmens have been the group that suffered the most. Since undoing the damage caused by radicalization will take a long time and the radicalization among different groups is mutually reinforcing each other, it will continue to be a problem even after the ISIS threat is eradicated and the Syrian crisis comes to an end.

The problems caused by different forms of internal displacement and forced migration remain there and they will continue to have negative societal effects on Iraq in the long-term. The perpetrator may be one of the several groups in deliberate acts of displacements: the ISIS, the Iraqi Army, the Shiite militias, the Peshmerga, or any other armed group from different ethnic or sectarian communities. The main reason for selective prevention of these displacements and especially returns is driven by political, rather than security motivations. This political motivation basically aims to provide ethnic/sectarian concentration in the regions under a specific group's control. Such acts change demographical geography, and are seen as gains by the actors who control such regions in the shortterm. However, it contains significant risks for the societal integrity of Iraq in the medium and long- 
term. The Iraqi people who suffered from such policies are losing their confidence in the state mechanisms and the political system at local, regional, and national levels, regardless of their identities. Moreover, arbitrary and selective practices make it difficult for the public to live together, not to mention the psychological trauma they cause. Such practices pave the way for radicalization and revanchist tendencies in the society.

Given the problems it experienced after 2003, Iraq faced very negative externalities of the Syrian crisis, in comparison to the other neighboring countries. In other words, when the effects of the Syrian crisis are added onto the existing structural problems in almost every issue, Iraq's challenges have become more complicated than before. It is vital to learn the lessons from the recent history for decreasing the effects of the crisis in the years to come, for Iraq seems unable to escape a vicious cycle of instability and conflict. Last but not the least, the need for planning for the post-crisis era in Iraq is urgent. Unless the factors that led to the expansion of the ISIS are not eliminated and the problems among the groups are not solved, Iraq will risk plunging back into a new wave of instability.

\section{BIBLIOGRAPHY}

Collard, R. (2014) “Life in Mosul Gets Back to Normal, Even With ISIS in Control”, Time, http://time.com/2901388/mosul-isis-iraq-syria/, (20.06.2014)

Duman, B. (2015a) “'A New Controversial Actor in Post-ISIS Iraq: Al-Hashd Al-Shaabi”, ORSAM Report No: 198

Duman, B. (2015b) “IŞİD’in Irak’ta Bir Yı11: Siyaset ve Güvenlik Algısının Dönüşümü’, Ortadoğu Analiz, Vol. 7, No. 69.

Fawcett, J. ve Cohen, R. (2002) “The Internally Displaced People of Iraq”, Brookings Institution.

Hoffman, B. (2004) “'Insurgency and Counterinsurgency in Iraq’, Rand Publications.

Human Rights Watch (2015a) “After Liberation Came Destruction: Iraqi Militias and the Aftermath of Amerli, 2015", https://www.hrw.org/report/2015/03/18/after-liberation-camedestruction/iraqi-militias-and-aftermath-amerli, (11.01.2016)

Human Rigths Watch (2015b) “'Iraqi Kurdistan: Arabs Displaced, Cordoned Off, Detained, 2015”, https://www.hrw.org/news/2015/02/25/iraqi-kurdistan-arabs-displaced-cordoned-detained, (11.01.2016)

Internal Displacement Monitoring Centre (2017) “'Iraq IDP Figures Analysis”, http://www.internaldisplacement.org/middle-east-and-north-africa/iraq/figures-analysis, (04.01.2018)

International Organization for Migration, (2013) “'Internal Displacement in Iraq: Barriers to Integration', 14. http://www.internal-displacement.org/assets/publications/2013/201312Internal-Displacement-in-Iraq-Barriers-to-Integration-eng.pdf, (04.04.2015). 
International Organization for Migration (2018) “Iraq Mission: Displacement Tracking Matrix”, http://iraqdtm.iom.int/, (03.02.2018).

Iraq News Net, (2014) “'Iraqi Resistance”, http://www.iraqnews.de/index.php?option=com_content\&task= view\&id=265\&Itemid=26, $(03.09 .2014)$

Kenyon Lischer, S. (2008) "Security and Displacement in Iraq: Responding to the Forced Migration Crisis", International Security, 33(2).

Lefler, J. (2014) "Life Under ISIS in Mosul”, Institute for the Study of War, http://iswiraq.blogspot.com.tr/2014/07/life-under-isis-in-mosul.html, (14.02.2015)

UNHCR (2013) Iraq Factsheet, Quarter 3, http://reliefweb.int/sites/reliefweb.int/files/resources/4c9084e49.pdf, (20.06.2014)

UNHCR (2014), “UNHCR Responds to Massive Displacement of Iraqis from Mosul’, http://www.unhcr.org/53989c766.html, (12.06.2014)

UNHCR (2015b) “'Registration Trends for Syrian Persons of Concern”, http://data.unhcr.org/syrianrefugees/country.php?id=103\#, (13.09.2015)

UNHCR (2018a) “'Syria Regional Refugee Response”, https://data2.unhcr.org/en/situations/syria, (04.03.2018)

UNHCR (2018b) “Operational Portal: Iraq”, https://data2.unhcr.org/en/situations/syria/location/5, (04.03.2018)

UNHCR, (2015a) “2015 UNHCR country operations profile - Iraq, Statistical Snapshot”, http://www.unhcr.org/pages/49e486426.html\#, (04.03.2018)

United States Department of State Office of the Coordinator for Counterterrorism (2006) "Country Reports on Terrorism 2005', 